\title{
ANALYSIS OF HOUSEHOLD FINANCIAL MANAGEMENT FOR WORK FROM HOME AFFECTED EMPLOYEES (CASE STUDY ON EMPLOYEES OF INSURANCE INDUSTRY COMPANIES IN SURABAYA)
}

\author{
Ninnasi Muttaqiin \\ Economic and Business Faculty, Universitas Nahdlatul Ulama Surabaya \\ e-mail:m.ninnasi@unusa.ac.id
}

\begin{abstract}
This study was conducted to examine the effect of work from home policy caused by coronavirus epidemic on household financial management of insurance industry employees in Surabaya. This study uses a qualitative method by conducting interviews. The variables used are household consumption, household savings, household investment, household insurance, and retirement planning. The sample selection using purposive sampling method, obtained seven sources who then provide answers to questions during in-depth interviews. The results showed that the work from home policy had a very significant effect on the condition of household financial management in the variables of household consumption, household savings, and household investment. On the other hand, work from home policy does not really affect household insurance management and retirement planning for employees of the insurance industry in Surabaya.
\end{abstract}

Keywords: work from home policy, household financial management

\section{INTRODUCTION}

The outbreak of the coronavirus epidemic has entered Indonesia since the beginning of 2020. Some institutions predicts the weakening of the world economy, including the International Monetary Fund (IMF) which projects the global economy to grow minus 3\%. The impact of the coronavirus epidemic outbreak to the economies of the world's countries also very powerful.

Some countries are still growing positively but decreased when compared to the quarter previous. The United States fell from 2.3 to 0.3 , South Korea from 2.3 to 1.3 and Vietnam from 6.8 to 3.8. Indonesia experience quite deep contractions of 4.97 in the 4th quarter of 2019 to only 2.97 in this first quarter.

The contraction deep enough in the 1 st quarter in Indonesia at beyond estimation considering physical distancing setting (PSBB) came into effect on early April 2020, which is in the 1st quarter (Q1) 2020 only reached 2.97 percent. The value landed far from its 1 st quarter target expected to reach a range of $4.5-4.6 \%$. Based on year-on-year growth, the source of Indonesia's economic growth on quarter 12020 in the information sector and communication by 0.53 percent. This matter reasonable considering the existence of suggestions for don't leave the house then a lot of people access work, entertainment and education through information technology.

Along with things that is, the sales volume of PLN electricity to household rises. Data from the Financial Services Authority (OJK) shows that general insurance and reinsurance premium income reached IDR 66.7 trillion by August 2020. This value is still growing 3.73\% year-on-year compared to August 2019 at IDR 64.3 trillion. Even though it is growing, based on a release from the Statistics Indonesia (BPS), 
number of foreign tourists who came to Indonesia in the first quarter of 2020 also dropped dramatically by only 2.61 million visits, reduced 34.9 percent if compared to last year, hotel occupancy in Bali is still at $2.5 \%$ and production of new vehicles this year is only around 24,000 , whereas last year it was 126,000 . The decline in vehicle production has affected the target market for vehicle insurance in Indonesia. These two declining areas of general insurance can affect the overall premium generation of the insurance industry.

The effect of coronavirus epidemic is compounded by restriction policy enforced up to the level of small business and business operations in Surabaya, East Java. One of the policies implemented in most companies is the work from home method or working flexibly from home. The implementation of this policy is enacted for an undetermined time which then, either directly or indirectly, will have an impact on financial management in the household level. Changes in the rhythm of working and carrying out the daily lives of employees certainly have an impact on household financial arrangements because there needs to be adaptations related to transportation costs, consumption costs, electricity costs, internet, and others.

This implementation is increasingly felt in the insurance business. In the insurance industry, to earn profits and gain customers, most of the employees are required to work on a mobile activity, do visiting to clients, insurance agents, broker insurance, and other parties. This mobile work pattern when limited to work from home policy will certainly bring significant changes to the financial condition of each employee, namely employees of the insurance industry. To examine the impact of the work from home policy on household financial management, it is necessary to have research aimed at analyzing the impact on employees using qualitative methods through interviews or interviews.

\section{METHODS}

The research paradigm used in this research is an interpretive paradigm which aims to emphasize more on subjective human experiences and someone's interpretations (Moleong, 2005). interpretive paradigm used to understand the meaning of an event and the effect on certain group of people, in this case is employees of insurance companies in Surabaya. The focus of this research is to know and analyze how the impact of work from home policy on employees of the insurance industry in Surabaya. The type of data in this study is primary data, which is obtained directly from interviews with respondents.

Secondary data used are obtained from external sources such as books, journals, and others. The qualitative technique used is interviews with selected respondents, and the interview technique used is in-depth interviews, where this technique means that there is a series of investigations who are asked one by one to the respondent with a direct interviewer to get an idea of what the subject thinks about something, or why do subjects do things in a certain way (Burns and Bush, 2010).

This technique is done directly face-toface and in depth to produce quality information. The time and location must be determined in advance before interviewing the respondent, the possibility of the interview being conducted at the respondent's place of business, or being flexible where the location can provide comfort for both the researcher and the respondent. Interviews will be conducted for 1-2 hours, once for one respondent. The validity of the 
data in a qualitative approach is obtained from the triangulation method, which is an attempt to obtain the correctness of the data by combining different ways to view the data (Silverman, 2005).

Triangulation is done by checking data from sources with different techniques. In this study, data were obtained through interviews and then checked by observation and documentation. If this check produces different results, the researcher will conduct further discussions with the data source to ensure that the data provided is correct (Sugiyono, 2016).

The selection of informants is carried out using a purposive sampling method based on the criteria that the informant is the branch manager of an insurance company in Surabaya, the informant is a worker who has experience in the insurance sector for more than five years, and applies the method of listening to employee aspirations or holding routine briefings with employees.

In addition, the selection of informants is also based on the ease with which researchers can access and the suitability of their backgrounds who can answer research questions. The former details of informant data in this study were hidden because of requests for privacy.

Table 1 Research Informant Data

\begin{tabular}{|c|c|c|c|c|c|}
\hline Number & Name & Age & $\begin{array}{c}\text { Sex } \\
(\mathbf{M} / \mathbf{F})\end{array}$ & $\begin{array}{c}\text { Work Exp. } \\
\text { (years) }\end{array}$ & $\begin{array}{c}\text { Company } \\
\text { Symbol }\end{array}$ \\
\hline $\mathbf{1}$ & A & 45 & M & 15 & X1 \\
\hline 2 & B & 50 & M & 20 & X2 \\
\hline 3 & C & 49 & F & 18 & X3 \\
\hline 4 & D & 53 & M & 21 & X4 \\
\hline 5 & E & 54 & M & 19 & X5 \\
\hline 6 & F & 56 & F & 27 & X6 \\
\hline 7 & G & 51 & M & 18 & X7 \\
\hline
\end{tabular}

\section{Data Analysis Technique}

Technique of data analysis in qualitative research is carried out when data collection takes place and is completed with data collection within a certain period (Sugiyono, 2016). At the time of the interview, the researcher had conducted an analysis of the interviewee's answers. Activities in data analysis are:

\section{Data reduction}

Reducing data means summarizing, selecting main things, focusing on important things, looking for themes and patterns and removing unnecessary ones, so that it will provide a clear picture and make it easier for researchers to collect data.

\section{Presentation of Data}

Presentation of data can be done in the form of brief descriptions, charts, relationships between categories and the like, where usually the most frequently used is narrative text.

\section{Conclusion Withdrawal}

The conclusions in qualitative research are new findings that have never existed before.

\section{Discussion and Conclusions}

\section{- Presentation of Data}

After the researcher went through the prefield stage, namely by preparing preparations to go to the field, the researcher conducted research into the field by means of in-depth interviews with seven informants, namely the branch manager of the insurance company in Surabaya who represented the aspirations of 
their employees, then by direct observation in the field, and using documents as research supporting data. To answer the focus of research on how the impact of work from home policies on employee household financial management, researchers conducted interviews with an average duration of about 1-2 hours of interviews with each informant. The demographics of the informants are as follows:

Table 2 Respondent Demographics

\begin{tabular}{|c|c|c|c|c|c|c|c|}
\hline No. & Name & $\begin{array}{l}\text { Age } \\
\text { (Yo) }\end{array}$ & $\begin{array}{l}\text { Sex } \\
(\mathrm{F} / \mathrm{M})\end{array}$ & $\begin{array}{l}\text { Work } \\
\text { Exp. } \\
\text { (Years) }\end{array}$ & Company & $\begin{array}{l}\text { Number of } \\
\text { Employees }\end{array}$ & $\begin{array}{c}\text { WFH } \\
\text { Period } \\
\text { (Months) }\end{array}$ \\
\hline 1 & A & 45 & M & 15 & $\mathrm{X} 1$ & 15 & 3 \\
\hline 2 & B & 50 & M & 20 & $\mathrm{X} 2$ & 25 & 5 \\
\hline 3 & C & 49 & $\mathrm{~F}$ & 18 & X3 & 18 & 5 \\
\hline 4 & $\mathrm{D}$ & 53 & M & 21 & $\mathrm{X} 4$ & 20 & 5 \\
\hline 5 & $\mathrm{E}$ & 54 & M & 19 & $\mathrm{X} 5$ & 35 & 4 \\
\hline 6 & $\mathrm{~F}$ & 56 & $\mathrm{~F}$ & 27 & $\mathrm{X} 6$ & 29 & 5 \\
\hline 7 & G & 51 & M & 18 & $\mathrm{X} 7$ & 33 & 4 \\
\hline
\end{tabular}

The researcher then analyzed the results of the interviews by finding patterns from the transcript of the interview results and formulating them in the report.

\section{Data Analysis}

This study focuses on understanding the impact of work from home policies on employees of insurance companies in Surabaya. Employees in the general insurance industry use outreach and mobile or visit methods to find new customers and maintain relationships with customers and various parties. With the application of the work from home work pattern, employee movements are limited so that it affects their bonus or commission earnings per period (month and year). This also has an impact on the financial management of employees' households, because while at home, activities from inside the house increase so that there is also an adjustment in the household financial management of each employee. The following will explain the qualitative analysis of the results of research by presenting the narratives of the informants which will then be used as discussion and material for making conclusions.

\section{The Impact of The Work From Home Policy on Household Consumption}

In this section, the researcher wants to know how the impact of WFH on the management of their household consumption. During WFH, employees will only spend time at home, so it is likely that the use of basic necessities will also increase, such as water, electricity, internet, food, and various other needs. Based on the results of interviews with informants, the results obtained were that seven informants felt that the implementation of WFH had an impact on the management of their household consumption. The following is a snippet of interviews from representatives of 3 informants:

"Kebijakan tersebut sangat terasa pada kami, karena pada penerapannya kami yang biasanya bekerja dari kantor atau mobile, jadi harus diam di rumah. Kerja juga dikontrol dengan terus-menerus menyalakan aplikasi zoom dan koordinasi kerja juga dilakukan dengan zoom, otomatis ngarub banget ke pengeluaran internet dan listrik. Kan di rumah biasanya tidak pakai banyak listrik, sekarang jadi di rumah 24 jam, ya listrik nyala terus, AC nyala terus. Belum lagi kalau jenuh kan dikit-dikit lapar, jadi makan terus, belum lagi jajan pesen online, jadi sebenernya sudah jalan 3 bulan WFH ini, tagihan listrik rumah saya naik $30 \%$. Kalau karyawan saya lainnya juga mengelubkan kalau konsumsi keseharian mereka juga ikutan naik, pulsa mereka juga karena harus beli kuota lebib kan. Kalau dibilang berdampak ya jelas berdampak sekali.” (Informant 5)

"Sangat berpengaruh ya Mba, apalagi kalau ditanya konsumsi rumah tangga sedangkan di rumah saya saja, empat orang yang kena dampak WFH, 
jadi empat orang beraktivitas dari rumah semua, pengeluaran jadi meningkat drastis. Ini sudah 4 bulan jalan, tagihan listrik dan internet naik dua kali lipat. Nah ngga tahu deh nanti sampai kapan ini kebijakannya, semoga lekas selesai ya." (Informant 6)

"Konsumsi rumah tangga secara umum naik, apalagi anak-anak saya kan juga di rumah, yang biasanya makan siang mereka dapat dari sekolah, ini jadi di rumah semua. Listrik paling berdampak, AC, TV, laptop pada nyala untuk kegiatan seharihari. Nah tapi di sisi lain, ini bisa main substitusi, jadi pengeluaran meningkat di electricity tapi di transportasi jadi kepangkas banyak banget karena ngga ke mana-mana kan. Jadi kalau dibilang berdampak, jelas tapi kurang yakin juga deh berdampak positifatau negatifnya." (Informant 3)

\section{The Impact of The Work From Home Policy on Household Savings}

In this section, the researcher wants to know how the impact of WFH on the management of their household savings. Based on the continuation of the questions about consumption, it is assumed that the implementation of WFH will also have an impact on household savings. When the percentage of household consumption increases, there will be an adjustment in the nominal amount of the savings allocation. The results of the interviews indicated that six informants felt that WFH had an impact on the size of the savings allocation, because some had to be sacrificed for household consumption post. One informant felt that there was no significant impact of WFH on the size of household savings because in the application of financial management, before it is used for consumption, income has been set aside for savings. The following is a snippet of interviews from representatives of 3 informants:

"Dalam pengelolaan rumah tangga, dikelola oleh istri saya, dan beberapa bulan ini beliau menge- luhkan bahwa tabungannya jadi berkurang karena digunakan untuk kebutuhan utama ya mungkin disebutkan konsumsi bulanan itu ya. Jadi kalau WFH ini terus berlangsung sampai akhir tahun, akan ada pemangkasan besar-besaran sepertinya di pengeluaran untuk konsumsi, karena sudah menuju parah ini jumlah tabungan rumah tangga." (Informant 2)

"Berdampak sib kalau ke tabungan, tapi dampak positif. Karena kan aku selalu nyisain uang untuk pos travelling, nab karena WFH jadinya ga bisa travelling ke mana-mana, yauda dana buat ke tabungan jadi makin bertambah. Biasanya ada juga dana buat entertain kan, buat belanja-belanja ngemall, ini ga dipake dananya, jadi ya dialibkan ke tabungan semua. Alhamdulillah tabungan jadi makin aman." (Informant 1 )

"Sejaub ini Alhamdulillah sib masib belum ada dampak signifikan ke jumlah tabungan. Saya dan istri juga sudah terbiasa berhemat dan mengelola dengan hati-hati, jadi tabungan masih aman. Lagi pula kalau tabungan, pengelolaannya emang uang diterima, langsung masuk pos tabungan dulu baru deh sisanya untuk konsumsi, jadi insya-Allah aman. Kalau berdampak ke konsumsi rumah tangga jelas, tapi kalau ke tabungan Alhamdulillah ngga sih, Mba." (Informant 4)

\section{The Impact of The Work From Home Policy on Household Investment}

In this section, the researcher wants to know how the impact of WFH on the management of their household investment. In financial management, after using income for consumption and savings, funds should be allocated for investment. Savings are funds that are more intended for the short term, while investment is setting aside funds to expect long-term returns or more than one year. The results of the interviews were that five informants concluded that WFH had an impact on their household investment, while two informants considered that there was no significant impact of WFH on investment management. The following is a snip- 
pet of interviews from representatives of 2 informants:

"Sama kayak tabungan sih, berdampak tapi lebih ke dampak positif karena kan jadi lebih banyak dana yang tidak terpakai, jadi bisa dialokasikan langsung ke investasi. Apalagi untuk mengelola investasi, saya pakai aplikasi dari handphone yang mudah ditambahkan nominalnya kapan saja dan berapa saja." (Informant 1)

"Kalau untuk investasi, WFH ini tidak berdampak pada investasi karena ya untuk investasi, saya sudah sisibkan dana sejak di awal tahun di bulan Januari kemarin. Jadi ketika pandemic, pengelolaan keuangan untuk alokasi ke investasi jadi aman, tidak berdampak apa-apa.” (Informant 7)

\section{The Impact of The Work From Home Policy on Household Insurance}

In this section, the researcher wants to know how the impact of WFH on the management of their household insurance. Insurance itself is a transfer of coverage to a third party for certain risks that may come in the future. Household insurance includes life insurance, health insurance, motor vehicle insurance, children's education insurance, and home insurance. The result of the interview showed that the seven informants agreed that WFH had no impact on household insurance management. The following is a snippet of interviews from representatives of 2 informants:

"Kalau asuransi kan kebanyakan sistemnya tahunan dan memang harus dibayarkan duluan supaya lebih aman ya. Jadi system WFH tidak berdampak banyak sih Mba ke alokasi asuransi rumah tangga.” (Informant 3)

"Ob tidak ada dampaknya kalau WFH ke pembayaran asuransi di keluarga saya. Kalau asuransi jiwa, kesehatan, dan pendidikan anak kan sudah disisihkan duluan. Jadi tidak bisa diganggu gugat selama tahun berjalan. Dan Alhamdulillah selama pandemic juga pengelolaan keuangan masih aman, jadi untuk asuransi rumah tangga juga aman." (Informant 4)

\section{The Impact of The Work From Home Policy on Retirement Planning}

In this section, the researcher wants to know how the impact of WFH on the management of their retirement planning. Retirement planning used to achieve financial freedom in the future. The result of the interview showed that the seven informants agreed that WFH had no impact on retirement planning. The following is a snippet of interviews from representatives of 2 informants:

\footnotetext{
"Sama seperti tabungan dan asuransi sib ya, ngga terlalu ada dampaknya WFH ke pengelolaan rencana pensiun, karena yang dipakai juga proses investasi untuk dana pensiun, jadi udah diatur duluan sejak awal." (Informant 1)

"Untuk rencana dana pensiun Alhamdulillah juga tidak terpengaruh. Kalau dana pensiun kan sudah nempel dengan rencana di asuransi jiwa jadi ya aman." (Informant 4)
}

\section{DISCUSSION}

Based on result of the interview, even insurance companies apply work from home policy, that does not effect much on household financial management. The policy might affect in the main factor, household consumption because it changes the consumption behavior that most of employees arrange in daily basis. Even though there has been an increase in expenditures in several aspects such as daily food, electricity, internet, and tertiary needs, work from home policy affected employees can still manage finances because the costs that should be used for transportation and eating out have decreased even to zero, so that this allocated to 
increase savings and investment. In the end, the system applied in household management is a substitution system. By experiencing an increase in spending on one post, there will be additional funds for other posts. For insurance planning and retirement planning, there is no significant impact because for these two posts, employees have implemented an allocation system at the beginning of the year and it is fixed, so that whatever their financial situation, funds for insurance and retirement planning will automatically be safe.

\section{CONCLUSIONS}

The results showed that the work from home policy had a very significant effect on the condition of household financial management in the variables of household consumption, household savings, and household investment. On the other hand, work from home policy does not really affect household insurance management and retirement planning for employees of the insurance industry in Surabaya.

\section{IMPLICATIONS AND LIMITATIONS}

\section{Implications}

The implication of this research is to broaden the insight into how the impact of the work from home policy implementation on insurance company employees in Surabaya. This research can also be used as material for employees to better manage household finances in order to anticipate emergencies such as the current pandemic. In addition, this research can provide inspiration for other researchers who want to develop research, as a reference for developing theories.

\section{Limitations}

The limitation of this study is the number of informants, which is only seven people. In addition, the questions only consist of the essence of household financial management, such as consumption, savings, investment, insurance, and retirement planning. The time period for conducting the research was also relatively short.

\section{REFERENCES}

Burns, A.C. and Bush, R. F. 2010. Marketing Research, $6^{\text {th }}$ Edition. Pearson.

Chong-Komo, Nanz. 2012. Bringing Out the Entrepreneur in You. Jakarta: PT Gramedia Pustaka Utama.

Financial Planning Standards Board Indonesia, 2020.

Franklin, Joyce L. 2014. Start-up Wealth: The Entrepreneur's Guide to Personal Financial Success and Long-Term Security. Rubydon Press.

Housel, M. 2020. The Psychology of Money: Timeless Lessons on Wealth, Greed, and Happiness. Harriman House Limited

Kobliner, Beth. 2000. Get a Financial Life: Personal Finance in Your Twenties and Thirties. Fireside Press.

Kiyosaki, Kim. 2006. Rich Women. Jakarta: PT Gramedia Pustaka Utama.

Moleong, J. Lexy. 2005. Metodologi Penelitian Kualitatif. Bandung: Remaja Rosdakarya. Muttaqiin, N., Agustina, H., \& Khusnah, H. 2018. Perencanaan Keuangan Pribadi untuk Remaja. Jurnal Unusa, 2(1), 17-20.

Ramsey, D. 2003. The Total Monet Makeover. Thomas Nelson.

Rattiner, Jeffrey H. 2005. Getting Started as a Financial Planner. Bloomberg Press. 
Senduk, Safir. 2000. Mengelola Keuangan Keluarga. Jakarta: PT Elex Media Komputindo. Silverman, D. 2005. Doing Qualitative Research: A Practical Handbook $2^{\text {nd }}$ Edition. Sage. Sugiyono. 2005. Metode Penelitian Bisnis. Jakarta: Alfabeta.

Suliyanto. 2006. Metode Riset Bisnis. Yogyakarta: Andi.
Sumarni, Murti dan Salamah Wahyuni. 2006. Metodologi Penelitian Bisnis. Yogyakarta : Andi.

Suryabrata, Sumadi. 2003. Metodologi Penelitian. Jakarta. Rajawali Pers. 